\title{
Problems Analysis About Needs on Development of Biology Learning Media for Junior High School Student in Digital Era
}

\author{
Wiwiek Okty Herlinda \\ Biology Education Program \\ Teacher Training and Education \\ Faculty of Mulawarman University \\ Samarinda, Indonesia \\ oktylinda@gmail.com
}

\author{
Muh. Amir Masruhim \\ Chemical Education Program \\ Teacher Training and Education \\ Faculty of Mulawarman University \\ Samarinda, Indonesia \\ amir.masruhim@fkip.unmul.ac.id
}

\author{
Sonja V.T. Lumowa \\ Biology Education Program \\ Teacher Training and Education \\ Faculty of Mulawarman University \\ Samarinda, Indonesia \\ verasonja@yahoo.com
}

\begin{abstract}
In digital era, teachers need pedagogical ability to create interesting and meaningful learning; development of learning media. The purpose of this study was to analysis problems in developing of learning media as a media to increase student learning outcomes. The research method was qualitative descriptive. The description of the problems was determined by interviews and questionnaires. This research was conducted at 5 junior high schools in Samarinda with science teachers and eighth-grade students as respondents. The results of the needs analysis show that 1 ) biology teachers were not creative and innovative enough on the development of biology learning media, 2) teachers have limited time to develop the learning media, 3) teachers have limited knowledge and ability to develop the learning media, and 4) student learning outcomes were low. It is clear that creativities of biology teachers at junior high school in Samarinda are needed to improve student learning outcomes.
\end{abstract}

Keywords: development, learning media, learning outcomes

\section{INTRODUCTION}

Education develops quickly. Lately, in digital era, many activities are facilitated by internet. In education, teachers play an important role in preparing young people. Therefore, teachers are required to be innovative, active and creative in improving the quality of education. As stated in the Regulation of National Education Minister No. 16 of 2007, information and technology is used by teacher in organizing learning activities [2].

According to the International Society for Technology in Education, teacher skills in the digital era are divided into five categories, that are 10 being able to facilitate and inspire learning and student creativity, 2) design and develop learning experiences and assessments of the digital era, 3) become a model of how to study and work in the digital era, 4) encourage and become a model of responsibility and digital society, and 5) participate in professional development and leadership [2]. The use of learning media greatly assists the teaching and learning process, so quality learning is created [8]. Learning Outcomes according to Gagne in Jufri [4], are abilities that can be observed in a person / capability. The success of the learning process will determine the quality of education, therefore the learning process needs to be chosen and done properly and correctly [3].

Based on observations and information obtained in the field, the teacher has not yet developed learning media, this can be seen when the teachers still us the old learning media such as chart, torso, video, power point but development of learning media cannot be seen. When surveying at school one of the reasons teachers have not yet developed learning media is the lack of time to create learning media, too much subject matter has to be completed so there is not enough time to create new learning media.

Another obstacle faced by teachers is the difficulty of providing understanding, especially related to the material systems of the body to humans such as the circulatory system, the respiratory system, the nervous system, and others. This has an impact on student learning outcomes that are less satisfying.

From the background description of the results of the questionnaire and teacher interviews, the authors consider that it is very important to conduct this research related to the development of learning media in the digital era in order to improve student learning outcomes. The purpose of this study is to analyze problems related to the needs of the development of learning media in the digital era to improve student learning outcomes.

\section{METHOD}

This research was needs analysis research and used survey method with questionnaires and unstructured interviews to collect data. Data would be analyzed qualitative descriptively. Respondents of the research were science teachers and eighth-grade student of some junior high schools in Samarinda city, East Kalimantan Province, Indonesia. This research was conducted at 3 public schools i.e. SMPN 4 Samarinda, SMP 5 Samarinda and SMPN 41 Samarinda, and 2 private schools i.e. SMP Muhammadiyah 1 Samarinda and SMPIT Cordova Samarinda.

\section{RESULT AND DISCUSSION}

Learning media is very important in the teaching and learning process. By using learning media, students are easily to understand and comprehend knowledge that delivered by teacher. Learning media are all physical tools that can deliver messages and facilitate students to learn such as books, films, contacts, and film frames [6]. Sadiman stated that media is everything that can be used to deliver messages from the sender to the recipient. Media help thoughts, feelings, concerns and interests, and concerns of students in learning process [9]. Learning media must be interesting and 
can make students interactive. These learning media make students fun and make the learning comfortable and conducive [5]. Affandi and Wibawanto stated that computerized technology makes media more interesting and interactive. As consequently, motivation and learning outcomes of students increased [1]. Student learning outcomes can be seen from their behavior such as their knowledge, thinking skills and motor skills [7].

These research findings are teachers do not understand the development of biology learning media at the junior high level in the digital era. It caused by teacher weaknesses in development innovative and creativity learning media. Teachers have limited ability and knowledge on the development of learning media in the digital era. In addition, Student learning outcomes were low.

This research found that, first, there were difficult topics in biological subject for students to understand. It was caused by the usage of conventional way by teachers in delivering knowledge. Teacher do not understand in development of biological learning media. As a conveyor of knowlege, teachers must be active and creative in learning process. Second, thechers have limited time to create learning media, so they use conventional learning media. Teachers must creative and innovative to create learning media, especially in this digital era. Third, students want a variety of learning resources. Varied learning resources can increase students' insights in learning process. Fourth, some students like textbooks, modules, and text as teaching materials, and others were prefer using different teaching materials. Theacher must develop interested teaching materials that can increase student motivation and learning outcomes.

TABLE I. OBSERVATIONS RESULTS

\begin{tabular}{|c|l|c|l|}
\hline No. & \multicolumn{1}{|c|}{ Aspect } & Percentage & \multicolumn{1}{|c|}{ Information } \\
\hline 1 & Material retention & $44 \%$ & $\begin{array}{l}\text { Biological science is difficult } \\
\text { for students to understand }\end{array}$ \\
\hline 2 & $\begin{array}{l}\text { Conventional } \\
\text { learning media }\end{array}$ & $83 \%$ & $\begin{array}{l}\text { The learning media used } \\
\text { conventionally }\end{array}$ \\
\hline 3 & $\begin{array}{l}\text { Learning resources } \\
\text { do not vary }\end{array}$ & $96 \%$ & $\begin{array}{l}\text { Students want a varied } \\
\text { learning resources }\end{array}$ \\
\hline 4 & $\begin{array}{l}\text { Teaching materials } \\
\text { usage }\end{array}$ & $59 \%$ & $\begin{array}{l}\text { Use of textbooks and } \\
\text { modules }\end{array}$ \\
\hline
\end{tabular}

\section{CONCLUSION}

Writer concludes that learning materials were weak because the process of teaching and learning using conventional learning media, learning resources were not varies, and the use of teaching materials need to be improved. Biological learning media at junior high school in Samarinda need to be developed in the digital era to improve student learning outcomes.

\section{ACKNOWLEDGMENT}

Authors are grateful to Dean of Teacher Training and Education Faculty of Mulawarman University for supporting this research.

\section{REFERENCES}

[1] U.C. Affandi and H. Wibawanto, "Pengembangan media animasi interaktif 3 (tiga) dimensi sebagai alat bantu ajar mata pelajaran IPA Kelas VII menggunakan blender game engine," Jurnal Teknik Elektro, vol. 7, 2005, pp. 62-70.

[2] Daryanto and S. Karim, Pembelajaran abad 21, Yogyakarta: Gava Media, 2017.

[3] S.C.P. Indriati, "Meningkatkan hasil belajar IPA konsep cahaya melalui pembelajaran science-edutaiment berbantuan media animasi," Jurnal Pendidikan IPA Indonesia, vol. 1, 2012, pp. 192-197.

[4] A.W. Jufri, Belajar dan pembelajaran sains modal dasar menjadi guru profesional, Bandung: Pustaka Reka Cipta, 2017.

[5] S.O. Meo and M.S. Masruri, "Keefektifan model pembelajaran dalam meningkatkan hasil belajar geografi ditinjau dari keterpaan media elektronik siswa SMA," Jurnal Pendidikan IPS, vol. 5, 2018, pp. 2029.

[6] A. Mudlofir and E.F. Rusydiyah, Desain pembelajaran inovatif, Jakarta: Raja Grafindo Persada, 2017.

[7] N.S. Sukmadinata, Landasan psikologi proses pendidikan, Bandung: Remaja Rosda Karya, 2011.

[8] E. Siswanah, "Penggunaan media animasi dalam pembelajaran trigonometri untuk meningkatkan hasil belajar mahasiswa tadris matematika IAIN Walisongo Semarang," Jurnal Phenomenon, vol. 2, 2013, pp. 5-17.

[9] A.K. Putri, "Pengembangan aplikasi bulaker adventure game sebagai media belajar berbasis android pada materi bangun ruang sisi lengkung," Jurnal Ilmiah Pendidikan matematika, vol. 3, 2016, pp. 36-42. 